\title{
Ontogeny of Fc Receptors and Complement Receptor (CR3) during Human Myeloid Differentiation
}

\author{
Howard B. Fleit, Samuel D. Wright, Catherine J. Durie, \\ Jay E. Valinsky, and Jay C. Unkeless \\ Department of Cellular Physiology and Immunology, \\ The Rockefeller University, and \\ The New York Blood Center, New York 10021
}

bstract. Two different Fc receptors for IgG $\left(\mathrm{Fc}_{\gamma} \mathrm{R}\right)$ have been identified on human leukocytes: a high avidity receptor $\left(\mathrm{Fc}_{\gamma} \mathrm{R}_{\mathrm{hi}}\right)$ present on monocytes but not on neutrophils, and a low avidity receptor $\left(\mathrm{Fc}_{\gamma} \mathbf{R}_{\mathrm{lo}}\right)$ present on neutrophils but not on monocytes. $\mathrm{Fc}_{\gamma} \mathrm{R}_{\mathrm{lo}}$ can be inhibited and the receptor precipitated by monoclonal antibody 3G8. We have used this monoclonal antibody to study the course of $\mathrm{Fc}_{\gamma} \mathrm{R}_{\mathrm{lo}}$ appearance on bone marrow cells, leukocytes of patients with chronic myelogenous leukemia (CML), and HL-60 and U937 cells induced to differentiate with agents such as dimethyl sulfoxide (DMSO), retinoic acid, phorbol myristate acetate, and lymphokine. We report that $\mathrm{Fc}_{\gamma} \mathbf{R}_{\mathrm{lo}}$ is a late differentiation antigen, first expressed at the metamyelocyte stage. Since precursors to metamyelocytes bear $F c_{\gamma} R$, and the promyelocyte line HL-60 bears $\mathrm{Fc}_{\gamma} R_{\mathrm{hi}}$, there must be a progressive loss of $F c_{\gamma} R_{h i}$ during myeloid differentiation and the reciprocal expression of $\mathrm{Fc}_{\gamma} \mathbf{R}_{\mathrm{lo}}$. Results of immunoprecipitation and polyacrylamide gel analysis of the proteins are consistent with these results.

We have also studied the receptor for the C3bi complement component (CR3), which is blocked and immunoprecipitated by monoclonal antibody OKM 10. During DMSO-driven differentiation of HL-60 cells, we find that CR3 is induced on all cells, whereas $F c_{\gamma} R_{l o}$ is

Dr. H. B. Fleit is an American Cancer Society Fellow, Dr. J. C. Unkeless is an American Cancer Society Research Scholar, and Dr. J. E. Valinsky is supported by a Research Career Development Award (CA-0633) from the National Cancer Institute.

Address requests for reprints to Dr. Fleit, at current address, Department of Pathology, State University of New York at Stony Brook, NY 11794. Dr. Valinsky is from The New York Blood Center. 1983.

Received for publication 12 July 1983 and in revised form 11 October

J. Clin. Invest.

(c) The American Society for Clinical Investigation, Inc. 0021-9738/84/02/0516/10 $\$ 1.00$

Volume 73, February 1984, 516-525

induced on only $24 \%$ of cells, suggesting that CR3 appears earlier during differentiation than $\mathrm{Fc}_{\gamma} \mathrm{R}_{\mathrm{lo}}$ does.

\section{Introduction}

Human polymorphonuclear leukocytes (PMN) develop from bone marrow myeloid stem cells, which divide until the metamyelocyte stage, at which time they undergo terminal differentiation. PMN maturation is characterized by the acquisition of polymorphic nuclear morphology and phagocytic and microbicidal capacity. These functional changes associated with maturation are likely to be accompanied by changes in plasma membrane constituents. The quantitative expression of plasma membrane components can now be studied with the use of monoclonal antibodies as probes.

$\mathrm{Fc}$ receptors for $\mathrm{IgG}\left(\mathrm{Fc}_{\gamma} \mathrm{R}\right)^{1}$ play a central role in effector cell recognition of foreign antigens via cytophilic IgG. An early suggestion that there might be more than one type of $\mathrm{Fc}_{\gamma} \mathrm{R}$ on human leukocytes came from observations that monocytes and PMN differ in their ability to rosette erythrocytes coated with anti- $\mathrm{Rh}_{0}$ sera (1). Kurlander and Batker (2) then demonstrated that PMN bind IgG1 oligomers with 100-1,000-fold lower avidity than do monocytes. The low avidity neutrophil $\mathrm{Fc}_{\gamma} \mathrm{R}$ $\left(\mathrm{Fc}_{\gamma} \mathrm{R}_{\mathrm{lo}}\right)$ bears an epitope recognized by monoclonal antibody 3G8, which blocks the binding of erythrocytes sensitized with IgG (EIgG) or soluble immune complexes to PMN (3). The specificity is similar to that of monoclonal B73.1, recently isolated by Perussia et al. (4). $3 G 8$ does not bind to monocytes, or the HL-60 or U937 cell lines, but does bind to peripheral blood neutrophils, eosinophils, most lung macrophages, and some lymphocytes. There are thus at least two receptors for IgG on human leukocytes, a low avidity receptor for immune complexes present primarily on $\mathrm{PMN}\left(\mathrm{Fc}_{\gamma} \mathrm{R}_{\mathrm{lo}}\right)$ and a high avidity receptor on monocytes $\left(\mathrm{Fc}_{\boldsymbol{\gamma}} \mathbf{R}_{\mathrm{hi}}\right)$.

1. Abbreviations used in this paper: ALL, acute lymphocytic leukemia; AML, acute myelogenous leukemia; AMoL, acute monocytic leukemia; APL, acute promyelocytic leukemia; $\mathrm{C}$, complement; $\mathrm{CML}$, chronic myelogenous leukemia; Con A, concanavalin A; CR3, complement receptor for C3bi; DMSO, dimethyl sulfoxide; DNP, dinitrophenyl; EIgG, IgG coated sheep erythrocytes; $\mathrm{Fc}_{\gamma} \mathrm{R}_{\mathrm{hi}}$, high avidity receptor for human IgG $1 ; \mathrm{Fc}_{\gamma} \mathbf{R}_{\mathrm{lo}}$, low avidity immune complex receptor; FBS, fetal bovine serum; PMA, phorbol myristate acetate. 
The receptor for the C3bi complement component (CR3) has recently been identified using the monoclonal antibodies OKM1 and OKM10 $(5,6)$. CR 3 consists of two peptides, an $\alpha$ of $185,000 M_{\mathrm{r}}$ and a $\beta$ of $105,000 M_{\mathrm{r}}$ and appears to be a member of a closely related family of two-chain leukocyte antigens. Each member of this family consists of a unique $\alpha$-chain noncovalently associated with a $\beta$-chain, which is identical for all members of the family $(5,6)$. The family includes: CR3, which is expressed on monocytes, macrophages, and PMN; LFA1 , which is associated with $T$ cell-mediated cytolysis, and is found on lymphocytes, monocytes, and macrophages; and a third protein of unknown function with an $\alpha$-chain of 153,000 $M_{\mathrm{r}}$. All members of the family share determinants, probably on the $\beta$-chain, which are recognized by monoclonal antibodies IB4 and TS1/8 $(5,6)$.

The HL-60 cell line has been used as a model for myeloid differentiation. HL-60 cells treated with dimethyl sulfoxide (DMSO) $(7)$ or retinoic acid $(8,9)$ differentiate in vitro to cells with more mature myeloid morphology and functional characteristics, whereas HL-60 cells incubated with phorbol myristate acetate (PMA) exhibit morphology more characteristic of monocytes (10). Similarly, the U937 cell line, which has monocytelike characteristics, responds to lymphokine or gamma interferon with an increased expression of $\mathrm{Fc}_{\gamma} \mathrm{R}_{\mathrm{hi}}(11-13)$. Myeloid precursors and mature PMN both have plasma membrane receptors for the Fc portion of $\operatorname{IgG}\left(\mathrm{Fc}_{\gamma} \mathrm{R}\right)$, as demonstrated by the ability of these cells to bind EIgG (14-17). We have studied the appearance of $F_{c_{\gamma}} R_{l o}$ and CR3 on HL-60 cells treated with inducing agents, on cells from human marrow, and on peripheral leukocytes from patients with chronic myelogenous leukemia $(C M L)$ and report that $F c_{\gamma} R_{l o}$ is a relatively late differentiation antigen.

\section{Methods}

Cells. HL-60 and U937 cells were grown in alpha modified Eagle's medium (Flow Laboratories, Inc., McLean, VA) supplemented with $10 \%$ heat inactivated fetal bovine serum (FBS) (Kansas City Biological, Lenexa, KA), $100 \mathrm{U} / \mathrm{ml}$ penicillin, and $100 \mu \mathrm{g} / \mathrm{ml}$ streptomycin (complete $\alpha$-minimal essential medium [ $\alpha$-MEM]). Cells were cultured in suspension using spinner flasks, or in tissue culture plastic dishes (Nunc, Denmark).

Bone marrow samples drawn from leukemic patients for clinical evaluation were obtained from the Tumor Procurement Center of the Sloan-Kettering Institute, New York. The bone marrow suspensions (usually $2 \mathrm{ml}$ ) were diluted with an equal volume of phosphate-buffered saline (PBS), and then mixed with an equal volume of $6 \%$ dextran in saline (21). After standing for $30 \mathrm{~min}$ at $37^{\circ} \mathrm{C}$, the leukocyte-rich supernatant was collected and the cells washed three times with PBS by centrifugation $(200 \mathrm{~g}, 10 \mathrm{~min})$.

For induction experiments, HL-60 cultures $\left(1.8 \times 10^{5}\right.$ cells $\left./ \mathrm{ml}\right)$ were cultivated in complete $\alpha$-MEM containing either $1.25 \%$ (vol/vol) DMSO (J. T. Baker Chemical Co., Philipsburg, NJ) (7) or $1 \mu \mathrm{M}$ retinoic acid (Sigma Chemical Co., St. Louis, MO) (8) for a total of $6 \mathrm{~d}$. HL-60 cells $\left(5 \times 10^{5} / \mathrm{ml}\right)$ were treated with $16 \mathrm{nM}$ PMA (Sigma Chemical Co.) in complete medium for $2 \mathrm{~d}$. Concanavalin $\mathrm{A}$ (Con A) supernatants were prepared by incubation of Ficoll-Hypaque-purified human mononuclear cells $\left(4 \times 10^{6}\right.$ cells $\left./ \mathrm{ml}\right)$ in RPMI 1640 (Gibco Laboratories, Grand
Island, NY) containing $10 \%$ FBS and $15 \mu \mathrm{g} / \mathrm{ml}$ of Con A (Miles Laboratories Inc., Ekhart, IN) (19). U937 cells $\left(2 \times 10^{5} / \mathrm{ml}\right)$ were cultivated in RPMI 1640 medium containing $25 \mathrm{mM}$ Hepes, $10 \% \mathrm{FBS}$, and either $10 \%$ of Con A supernatant or control supernatant from untreated mononuclear cells incubated in parallel.

Morphology and immunofluorescence. The percentage of viable cells was determined by trypan blue exclusion. For cell differential counts, $2-4 \times 10^{5}$ cells were centrifuged in a cytocentrifuge (Shandon cytospin, Shandon Southern Instruments, Inc., Sewickley, PA) and stained with Diff-quick (Harleco, Hartman-Leddon, Philadelphia, PA). 200-300 cells were counted per sample.

For immunofluorescence staining, cells were attached to poly-Llysine-coated glass. Either 13-mm No. 1 coverglasses (Propper Manufacturing Co., Inc., Long Island City, NY) or slides with 6-mm circles in a hydrophobic coating (Carlson Scientific, Peotone, IL) were acid washed with Chromerge (Fisher Scientific Co., Pittsburgh, PA) rinsed with water, coated with $50 \mu \mathrm{g} / \mathrm{ml}$ of poly-L-lysine $(70,000 \mathrm{~mol}$ wt, Sigma Chemical Co.) for $20 \mathrm{~min}$, and rinsed in water. Cells $\left(3-5 \times 10^{5}\right)$ suspended in PBS were either centrifuged $\left(200 \mathrm{~g}, 8 \mathrm{~min}, 4^{\circ} \mathrm{C}\right)$ onto coverglasses, or were allowed to settle $\left(20 \mu \mathrm{l}\right.$ cell suspension at $2 \times 10^{6}$ cells $/ \mathrm{ml}$ ) onto the masked slides $\left(45 \mathrm{~min}\right.$ at $\left.4^{\circ} \mathrm{C}\right)$. Unreacted cationic sites were then quenched with PBS containing 5\% FBS.

Cell preparations were incubated with $3 \mathrm{G} 8 \mathrm{Fab}(50 \mu \mathrm{g}$ per $\mathrm{ml})$ in PBS containing 5\% FBS for $45 \mathrm{~min}$ at $4^{\circ} \mathrm{C}$. The cells were rinsed in PBS-5\%FBS, incubated $\left(30 \mathrm{~min}, 4^{\circ} \mathrm{C}\right)$ with either biotinylated rabbit $\mathrm{F}\left(\mathrm{ab}^{\prime}\right)_{2}$ anti-mouse IgG prepared as described (20) or a biotinylated horse anti-mouse Ig (Vector Laboratories, Burlingame, CA) at a concentration of $50 \mu \mathrm{g} / \mathrm{ml}$ in PBS-5\%FBS, rinsed, and stained $\left(30 \mathrm{~min}, 4^{\circ} \mathrm{C}\right)$ with fluoresceinated Avidin-D (Vector Laboratories) at a concentration of $50 \mu \mathrm{g} / \mathrm{ml}$ in PBS-5\%FBS. After final rinsing, cells were fixed in buffered $10 \%$ formalin, and mounted in $90 \%$ glycerol, 10\% PBS containing 1 $\mathrm{mg} / \mathrm{ml}$ p-phenylenediamine (Aldrich Chemical Co., Inc., Milwaukee, WI), to retard fluorescence quenching (21). The p-phenylenediamine stains the nuclei orange, enabling accurate assessment of nuclear morphology along with the green fluorescein fluorescence. This could not be done nearly as well from the phase image of the fixed cells. Cells were examined with epifluorescence optics using a $63 \times$ lens and photographed on Ektachrome ASA 400. Internegatives were made of the color slides on Ektapan film with a Kodak No. 25 red filter (Eastman Kodak Co., Rochester, NY.

Fluorescence-activated cell sorter analysis. Cells $\left(2 \times 10^{6}\right)$ were treated in suspension with identical concentrations of reagents used for immunofluorescence studies. Cells incubated with the rabbit anti-Fc ${ }_{\gamma} \mathbf{R}_{\mathbf{l}}$ $F\left(a b^{\prime}\right)_{2}$ were then stained with a fluoresceinated goat $F\left(a b^{\prime}\right)_{2}$ anti-rabbit IgG (Cappel Laboratories, Cochranville, PA). Cells were washed three times by centrifugation between each reagent. Flow microfluorometry was performed with a FACS II fluorescence-activated cell sorter (Becton, Dickinson \& Co., Mountain View, CA). Exciting light at $488.8 \mathrm{~nm}$ was provided by a 5-W argon-ion laser (Spectra-Physics Inc., Mountain View, CA) at an incident power of $300 \mathrm{~mW}$. Emitted light was optically filtered with 520-nm and 530-nm "cut-on" filters (Ditrich Optics, Marlboro, MA.) placed in series. In all cases the photomultiplier tube was set at 2/1. Fig. 2 was obtained by tracing photographs of the oscilloscopic displays, and the results presented are typical of four separate experiments. In each case controls omitting $3 \mathrm{G} 8 \mathrm{Fab}$ or the rabbit anti-Fc $\mathrm{R}_{\mathrm{lo}} \mathrm{F}\left(\mathrm{ab}^{\prime}\right)_{2}$, and controls using an irrelevant $\mathrm{Fab}$ or rabbit $\mathrm{F}\left(\mathrm{ab}^{\prime}\right)_{2}$ reagent were included. Fluorescence gain settings were $8 / 1$ for cells stained with 3G8 or the rabbit anti- $\mathrm{Fc}_{\gamma} \mathrm{R}_{\mathrm{oo}} \mathrm{F}\left(\mathrm{ab}^{\prime}\right)_{2}$ and 8/0.7 for cells stained with OKM10.

Ligands and binding studies. Purification of monoclonal antibody and papain Fab fragments was as described $(3,25)$. Human IgG1 myeloma protein $(\mathrm{Ba})$ was a gift of Dr. Edward Franklin (New York Uni- 
versity School of Medicine). OKM10 was the generous gift of Dr. Gideon Goldstein (Ortho Pharmaceutical, Raritan, NJ). Proteins were labeled with ${ }^{125}$ I using Iodo-gen (Pierce Chemical Co., Rockford, IL) as the oxidizing agent $(23,24)$. We routinely obtained $50-70 \%$ incorporation of label into protein, with a final specific activity of $5,000 \mathrm{cpm} / \mathrm{ng}$ protein.

$A$ rabbit antiserum against $\mathrm{Fc}_{\gamma} \mathbf{R}_{\mathrm{b}}$ was prepared by injecting purified $\mathrm{Fc}_{\gamma} R_{\mathrm{to}}(25)(60 \mu \mathrm{g})$ in complete Freund's adjuvant into two popliteal lymph nodes as previously described (26) and four subcutaneous sites. $19 \mathrm{~d}$ later, the rabbit was boosted with $20 \mu \mathrm{g} \mathrm{Fc}_{\gamma} \mathrm{R}_{\mathrm{lo}}$, which had been boiled in $0.1 \%$ sodium dodecyl sulfate (SDS) and emulsified in incomplete Freund's adjuvant. At the same time, $\mathrm{Fc}_{\boldsymbol{\gamma}} \mathbf{R}_{\mathrm{lo}}$ was immunoprecipitated from $2.7 \times 10^{9} \mathrm{PMN}$ with $3 \mathrm{G} 8 \mathrm{Fab}$ Sepharose, emulsified in incomplete Freund's adjuvant and injected subcutaneously. This procedure was performed to enhance the antibody response to sites other than that recognized by the monoclonal antibody 3G8 (27). The IgG fraction of the rabbit anti-FcR was prepared by ammonium sulfate precipitation and purified by chromatography on a TSK-3000 column (LKB, Stockholm, Sweden). The $F\left(a b^{\prime}\right)_{2}$ fragment was prepared by pepsin digestion and similarly chromatographed on a TSK-3000 column. The ability of $F\left(a b^{\prime}\right)_{2}$ fragments of the anti-Fc ${ }_{\gamma} R_{10}$ IgG and control rabbit IgG to inhibit binding of soluble rabbit antidinitrophenyl (DNP) IgG-DNP, BSA complexes prepared as described (3) was tested following preincubation of the neutrophils for $1 \mathrm{~h}$ with the $\mathrm{F}\left(\mathrm{ab}^{\prime}\right)_{2}$ preparations.

The binding of labeled $3 \mathrm{G} 8 \mathrm{Fab}$ or monomeric IgG1 was performed using saturating concentrations of antibody as described previously (3). Briefly, cells $\left(5-20 \times 10^{5}\right)$ were incubated $\left(1 \mathrm{~h}, 4^{\circ}\right)$ in $0.1 \mathrm{ml}$ of PBS containing $1 \mathrm{mg} / \mathrm{ml}$ bovine serum albumin (PBS-BSA) and $2 \mu \mathrm{g} / \mathrm{ml}$ of labeled ligand $(2,000-4,000 \mathrm{cpm} / \mathrm{ng}$ protein). To remove unbound ligand the cells were diluted with $2.5 \mathrm{ml}$ PBS-5\%FBS, and the suspension was centrifuged. The cell pellet was resuspended in $1 \mathrm{ml}$ of PBS-5\%FBS, centrifuged, and the radioactivity in the cell pellet was determined. Results were corrected for nonspecific binding by subtraction of radioactivity bound using an equivalent input of radioactivity in labeled ligand of low specific activity $(10 \mathrm{cpm} / \mathrm{ng})$.

Cell labeling and immunoprecipitation. Cells were labeled with ${ }^{125} \mathrm{I}$ using lactoperoxidase and glucose oxidase (28). The labeled cells were lysed in PBS containing 0.5\% Nonidet P-40 (NP-40), $1 \mathrm{mM}$ phenylmethylsulfonylfluoride (PMSF), and $0.28 \mathrm{IU}$ aprotinin/ml (29). 3G8 Fab, IB4 IgG, and monomeric IgGl were coupled to CNBr-activated Sepharose $4 B$ at 2-4 $\mathrm{mg}$ protein $/ \mathrm{ml}$ of Sepharose. The rabbit anti- $F \mathrm{c}_{\gamma} \mathbf{R}_{\mathrm{lo}}$ serum prepared by immunization with purified FcR (25) was adsorbed to fixed Staphylococcus aureus (Zymed Laboratories), which were then washed by centrifugation in the lysis buffer. The lysate of the labeled cells, after clearing $(40,000 \mathrm{~g}, 30 \mathrm{~min})$, was incubated $\left(1 \mathrm{~h}, 4^{\circ} \mathrm{C}\right)$ on a shaker with the immunoadsorbents, which were then washed twice with a high salt buffer $\left(0.6 \mathrm{M} \mathrm{NaCl}, 0.0125 \mathrm{M} \mathrm{KPO}_{4}, \mathrm{pH} 7.4,0.02 \% \mathrm{NaN}_{3}\right)$, twice with a mixed micelle buffer $(0.05 \%$ NP- $40,0.1 \%$ SDS, $10 \mathrm{mM}$ Tris, $\mathrm{pH} 8.6,0.3 \mathrm{M} \mathrm{NaCl})$, and again with the high salt buffer $(29,30)$. Adsorbed protein was eluted with sample buffer and electrophoresed on 1-mm-thick slab gels with a 4-11\% polyacrylamide gradient (31). The dried gels were exposed at $-70^{\circ} \mathrm{C}$ on Kodak X-Omat AR film using enhancing screens (DuPont Instruments, Wilmington, DE). The results presented are typical of at least four experiments.

\section{Results}

Induction of $F c_{\gamma} R_{l o}$ on $H L-60$ cells. The HL-60 cell line has been widely used as a model for myeloid differentiation since culture with compounds such as retinoic acid and DMSO results in the differentiation of these cells to more "mature" forms (79). In agreement with previously published reports (7), we found $>95 \%$ of uninduced HL60 cells resembled promyelocytes. Culture with DMSO and to a lesser extent with retinoic acid, resulted in the appearance of a large percentage of cells resembling metamyelocytes, and a small percentage of more mature forms (Table I). We examined by immunofluorescent staining HL-60 cells that had been induced to differentiate and found a correlation between the extent of differentiation as judged by morphology and expression of $\mathrm{Fc}_{\gamma} \mathrm{R}_{\mathrm{lo}}$ (Table I, Fig. 1). Incubation with DMSO (Fig. $1 \mathrm{~B}$ ) and retinoic acid (Fig. $1 \mathrm{C}$ ) resulted in fluorescent staining by $3 \mathrm{G} 8$ on $24.3 \%$ and $5.2 \%$ of the cells, respectively, compared with $<0.2 \%$ of the uninduced population (Table I, Fig. 1). Incubation of the HL-60 cells with PMA did not result in staining with 3G8 (Table I, Fig. $1 \mathrm{D}$ ). The few positive cells present in the uninduced population of HL-60 cells stained with 3G8 had metamyelocyte nuclear morphology and had matured spontaneously without the addition of any drug (7) (Table I).

Table I. Effect of Inducers on $R f_{\gamma} R_{l o}$ and IB4 Antigen Expression by HL-60 and U937 Cells

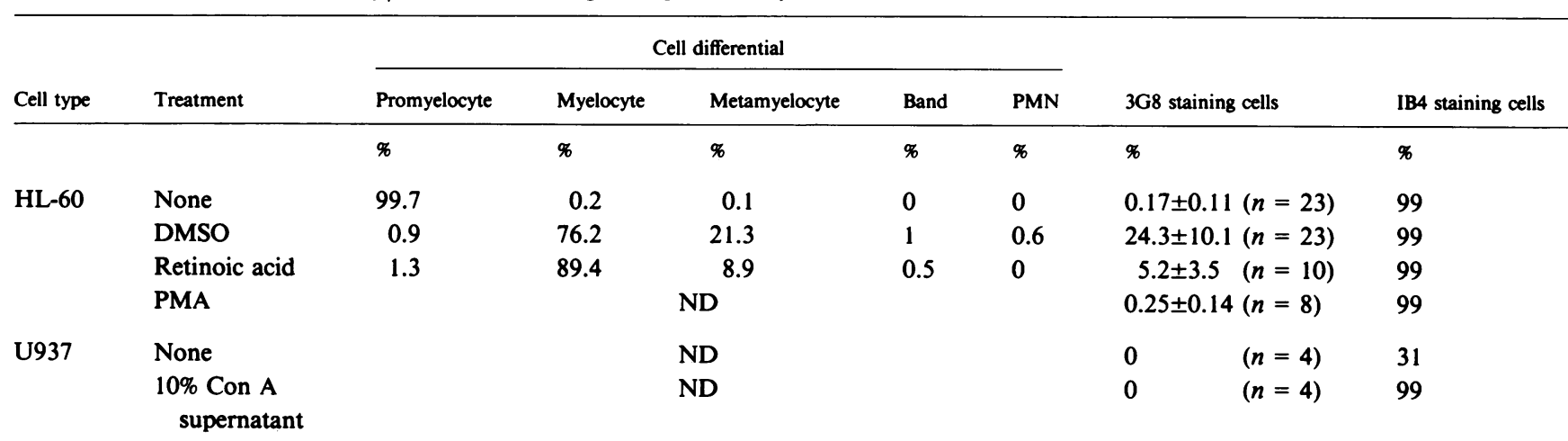

Differentials were determined by Diff-Quik staining as described. 3G8- and IB4-positive populations were determined by immunofluorescent staining. Concentrations of inducers were DMSO, 1.25\% (vol/vol); retinoic acid, $1 \mu \mathrm{M} ; \mathrm{PMA}, 16 \mathrm{nM}$. 

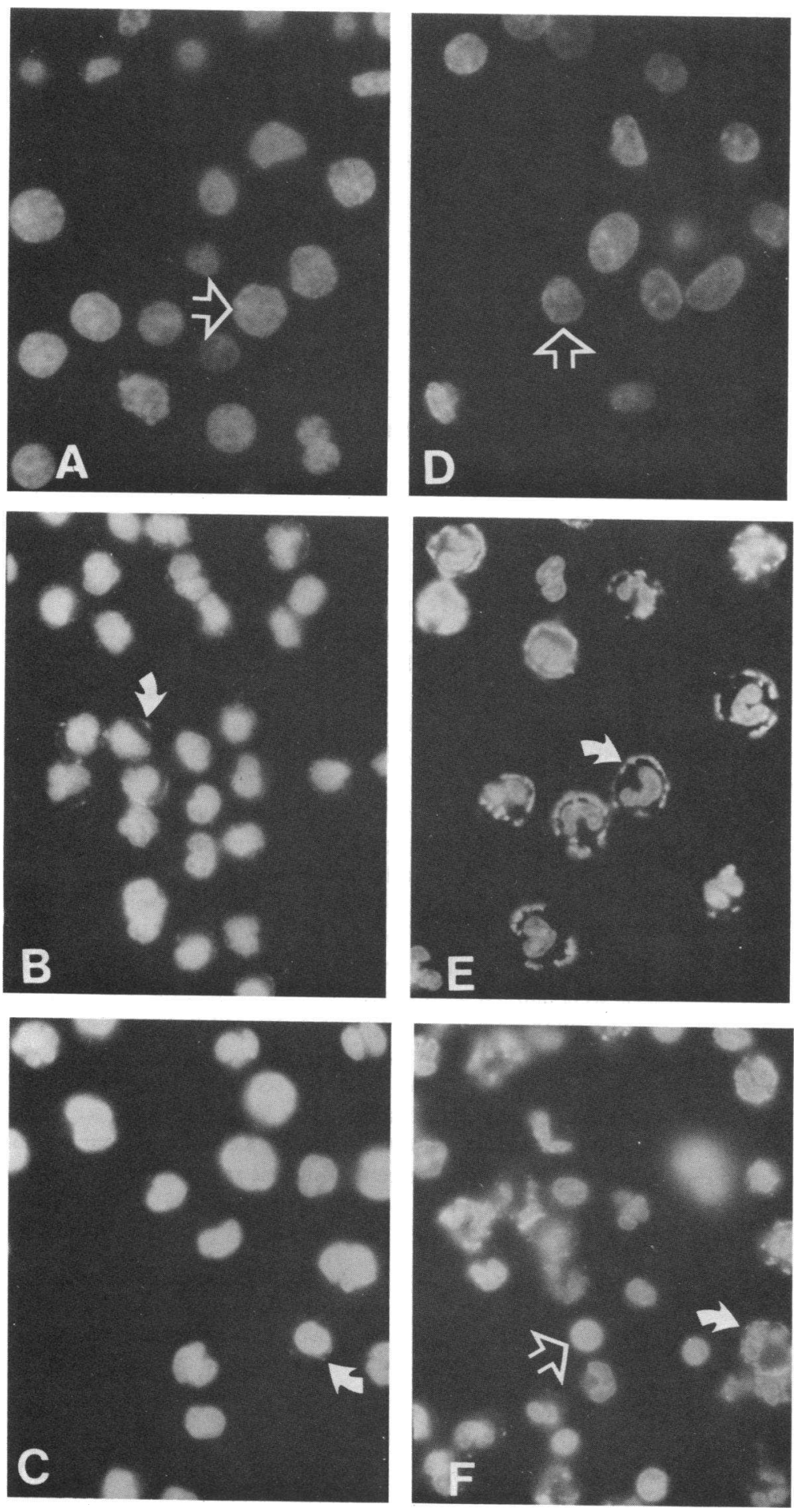

Figure 1. Immunofluorescent staining by $3 \mathrm{G} 8$ of HL-60 cells, peripheral blood PMN, and bone marrow leukocytes. Cells were prepared as described in the Methods section. $(A)$ HL-60 cells. $(B)$ HL-60 cells treated with DMSO. $(C)$ HL-60 cells treated with retinoic acid. $(D)$ HL-60 cells treated with PMA. (E) PMN. $(F)$ Bone marrow leukocytes. The solid arrows point out membrane fluorescence (green in the original transparency) and the hollow arrows indicate nuclear fluorescence (orange in the original).

In agreement with the results obtained by immunofluorescence, quantitative binding studies using ${ }^{125}$ I-labeled 3G8 Fab and monomeric IgG1 showed there was no detectable binding of 3G8 Fab on uninduced HL-60 cells (3) nor on PMA-treated HL-60 cells (Table II). In contrast, significant binding of ${ }^{125} \mathrm{I}$ 3G8 Fab was demonstrated on both DMSO- and retinoic acid- 


\begin{tabular}{|c|c|c|c|}
\hline \multirow[b]{2}{*}{ Cell type } & \multirow[b]{2}{*}{ Treatment } & $3 G 8 \mathrm{Fab}^{*}$ & $|g G| t$ \\
\hline & & $\begin{array}{l}\text { Number of sites per 3G8- } \\
\text { positive cell }\end{array}$ & Average number of sites \\
\hline \multirow[t]{4}{*}{ HL-60 } & None & $0 \quad(n=12)$ & $3.37 \pm 1.86 \times 10^{3}(n=12)$ \\
\hline & DMSO & $3.14 \pm 1.13 \times 10^{4}(n=10)$ & $4.00 \pm 1.43 \times 10^{3}(n=11)$ \\
\hline & Retinoic acid & $3.64 \pm 0.82 \times 10^{4}(n=7)$ & $8.45 \pm 2.6 \times 10^{3} \quad(n=8)$ \\
\hline & PMA & $0 \quad(n=5)$ & $1.25 \pm 2.0 \times 10^{4} \quad(n=5)$ \\
\hline \multirow[t]{2}{*}{ U937 } & None & $(n=3)$ & $8.3 \pm 2.5 \times 10^{3} \quad(n=5)$ \\
\hline & $10 \%$ Con A supernatant & $(n=3)$ & $2.2 \pm 0.7 \times 10^{4} \quad(n=5)$ \\
\hline
\end{tabular}

Concentrations of inducers were as in Table I. * Binding values are corrected to determine the number of sites per positive cell. $¥$ Binding values represent population averages.

treated cells. Furthermore, when binding data were analyzed with respect to the percentage of positive cells (Table I) a comparable number of $3 \mathrm{G} 8$ Fab-binding sites per positive cell was found for both the DMSO- and retinoic acid-induced populations (Table II).

HL-60 cells, unlike peripheral neutrophils, have a high avidity $\mathrm{Fc}_{\gamma} \mathrm{R}$ for monomeric human IgG1 $\left(\mathrm{Fc}_{\gamma} \mathrm{R}_{\mathrm{hi}}\right)$ (32). Binding of IgG1 to DMSO-induced HL-60 cells was comparable to uninduced cultures (Table II). Incubation of HL-60 cells with PMA, however, resulted in a threefold increase in the amount of IgG 1 bound.

Effect of lymphokine on $F c_{\gamma} R$ expression by U937 cells. The U937 cell line is a monocytelike line that responds to treatment with lymphokine preparations or gamma interferon with an increase in $\mathrm{Fc}_{\gamma} \mathrm{R}_{\mathrm{hi}}$ expression $(12,13)$. We examined whether the expression of $\mathrm{Fc}_{\gamma} \mathrm{R}_{\mathrm{to}}$ could be induced on U937 cells following culture for $48 \mathrm{~h}$ in medium containing $10 \%$ of a supernatant from mononuclear cells treated with Con A. Immunofluorescence studies of untreated or lymphokine-treated U937 cells failed to demonstrate any cells expressing $\mathrm{Fc}_{\gamma} \mathrm{R}_{\mathrm{lo}}$ (Table I). In contrast, the binding of ${ }^{125} \mathrm{I}-\mathrm{IgG} 1$ to the lymphokine-treated U937 cells increased by almost threefold (Table II), in agreement with the results of Guyre et al. $(12,13)$.
Expression of $C R 3$ on $H L-60$ and $U 937$ cells. The monoclonal antibody OKM10 recognizes CR3 of human leukocytes (5). We examined the expression of this receptor on HL-60 cells and on HL-60 cells induced to differentiate with DMSO or retinoic acid. HL-60 cells express no CR3 as assessed by the binding of OKM10 (Fig. $2 C$ ). However, treatment with DMSO or retinoic acid resulted in the expression of this receptor on all cells as determined by fluorescence-activated cell sorter analysis (Fig. $2 C$ ).

We also examined the expression of antigens recognized by the antibody IB4, which recognizes a determinant shared by at least three members of a family of two-chain leukocyte membrane proteins $(5,6)$. All HL-60 cells and $30 \%$ of U937 cells expressed low levels of fluorescent staining with IB4 (Table I). However, after incubation with lymphokine, $>99 \%$ of U937 cells were stained with IB4.

To quantitate our results on a per cell basis, we also performed cell sorter analysis on drug-induced and control HL-60 populations (Fig. $2 A$ and $B$ ). Fluorescence-activated cell sorter analysis demonstrated a shift to the left in the light scatter of the DMSO-treated HL-60 cells indicative of the appearance of smaller cells. The fluorescence analysis revealed that $22.3 \%$ of the DMSO-treated cells were $3 \mathrm{G} 8$ positive (Fig. $2 \mathrm{~A}$ ).

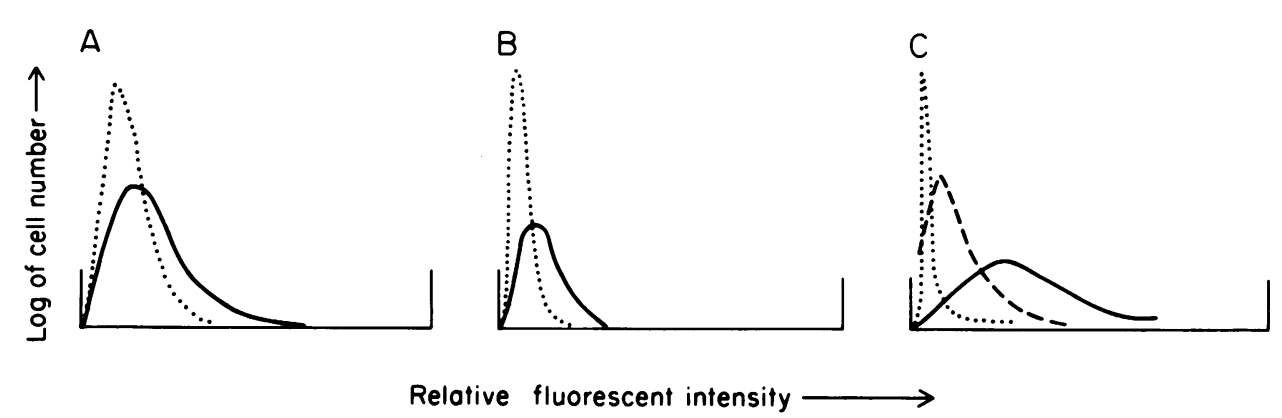

Figure 2. Fluorescence-activated cell sorter analysis of HL-60 or DMSOinduced HL-60 cells stained with 3G8 Fab, rabbit anti-Fc $\mathrm{C}_{\boldsymbol{\gamma}} \mathbf{R}_{\mathrm{to}}$, and OKM 10. $(A)$ Binding of $3 G 8$ to HL-60 cells $(\cdots \cdots)$ and HL-60 cells treated with DMSO $(-)$. (B) Binding of rabbit anti-Fc $\mathrm{R}_{\mathrm{lo}} \mathrm{F}\left(\mathrm{ab}^{\prime}\right)_{2}$ to HL-60 cells $(\cdots \cdots)$ and HL-60 cells treated with DMSO (-). (C) Binding of OKM 10 to HL-60 cells $(\cdot \cdots)$, HL-60 cells treated with retinoic acid (-...-), or HL-60 cells treated with DMSO (-). 
Cell sorter analysis was also performed with rabbit anti$\mathrm{Fc}_{\gamma} \mathrm{R}_{\mathrm{lo}} \mathrm{F}\left(\mathrm{ab}^{\prime}\right)_{2}$, obtained by immunizing a rabbit with purified $\mathrm{Fc}_{\gamma} \mathrm{R}_{\mathrm{lo}}$ obtained from neutrophils by affinity chromatography. This antiserum immunoprecipitated the same protein from labeled cells as the monoclonal antibody (Fig. 3, lanes $b-e$ ). Furthermore, $F\left(a b^{\prime}\right)_{2}$ fragments of the antiserum inhibited the binding of soluble immune complexes to peripheral neutrophils, whereas control rabbit $F\left(a b^{\prime}\right)_{2}$ had no effect (Fig. 4). When the rabbit anti $\mathrm{Fc}_{\gamma} \mathrm{R}_{10}$ serum was used to stain DMSO-treated HL60 cells, a slightly higher percentage of staining was found (31.9\%) than with $3 \mathrm{G} 8 \mathrm{Fab}$, suggesting that this antisera might crossreact with epitopes on other Fc receptors (Fig. $2 B$ ). We also found that only a fraction of DMSO-induced HL-60 cells stained with $3 \mathrm{G} 8$ whereas the same cells stained uniformly with OKM10 (Fig. 2 C).

Expression of the $3 G 8$ and IB4 antigens by cells from CML patients or leukemic bone marrow. Another model for neutrophil maturation is found in patients with CML. In the peripheral circulation of these patients cells with mature neutrophil morphology as well as less differentiated cells are found. We reported previously that the less dense (immature) cells had fewer binding sites for 3G8 (3). Immunofluorescence studies (Table III) confirm this and demonstrate that cells exhibiting nuclear morphology earlier than the metamyelocyte stage lack $\mathrm{Fc}_{\gamma} \mathbf{R}_{\mathrm{lo}}$, while the cells at or beyond the metamyelocyte stage stain with essentially the same fluorescence intensity as peripheral neutrophils. In parallel with immunofluorescence studies for $\mathrm{Fc}_{\gamma} \mathrm{R}_{\mathrm{lo}}$, we also examined IB4 antigen expression on leukocytes from CML patients. Of the peripheral leukocytes from two patients, 14 and $68 \%$ were positive for $3 \mathrm{G} 8 ; 68$ and $76 \%$ respectively, were positive for IB4. Some lymphocytes and blastlike cells were IB4-negative, but it is clear that IB4 stains a larger percentage of immature myeloid precursors than $3 \mathrm{G} 8$ does.

A series of bone marrow samples from patients with leukemia or in remission (acute myelopenous leukemia [AML], acute promyelocytic leukemia [APL], acute monocytic leukemia [AMoL], and acute lymphocytic leukemia [ALL]) was examined in order to determine the stage of myeloid development at which the antigen recognized by $3 G 8$ could be detected. During preliminary experiments, we made the fortuitous observation that inclusion of $p$-phenylenediamine in the mounting fluid, which dramatically slows the rate of fluorescence bleaching (21), resulted in orange staining of nuclei. This enabled us to score accurately 3G8 Fab staining and nuclear morphology on the same cells. We found that only cells at the metamyelocyte stage of development or beyond expressed $\mathrm{Fc}_{\gamma} \mathbf{R}_{\mathrm{lo}}$ (Table IV). Indeed, the intensity of fluorescence was greatest on cells with fully mature nuclear morphology (Fig. $1 F$ ). Cells with round or blastlike nuclear morphology did not demonstrate any fluorescent staining.

Immunoprecipitation of $F c_{\gamma} R$. To extend the above results, we performed immunoprecipitation studies on ${ }^{125}$ I-labeled cells with monoclonal and polyvalent sera and analyzed the labeled proteins by SDS-polyacrylamide gel electrophoresis. Immunoprecipitation of NP-40 lysates from surface-labeled DMSOtreated HL-60 cells and peripheral blood PMN with either 3G8 Fab or a rabbit anti- $F c_{\gamma} R_{l o}$ antiserum yielded identical proteins with broad electrophoretic mobility, from 50,000 to $74,000 M_{\mathrm{r}}$ and from 56,000 to $74,000 M_{\mathrm{r}}$, respectively (Fig. 3, lanes $b-e$ ), confirming that the two sera react with the same protein. The rabbit antisera to $F c_{\gamma} R_{\mathrm{lo}}$ precipitated a larger amount of this polypeptide than did $3 \mathrm{G} 8 \mathrm{Fab}$. As expected on the basis of

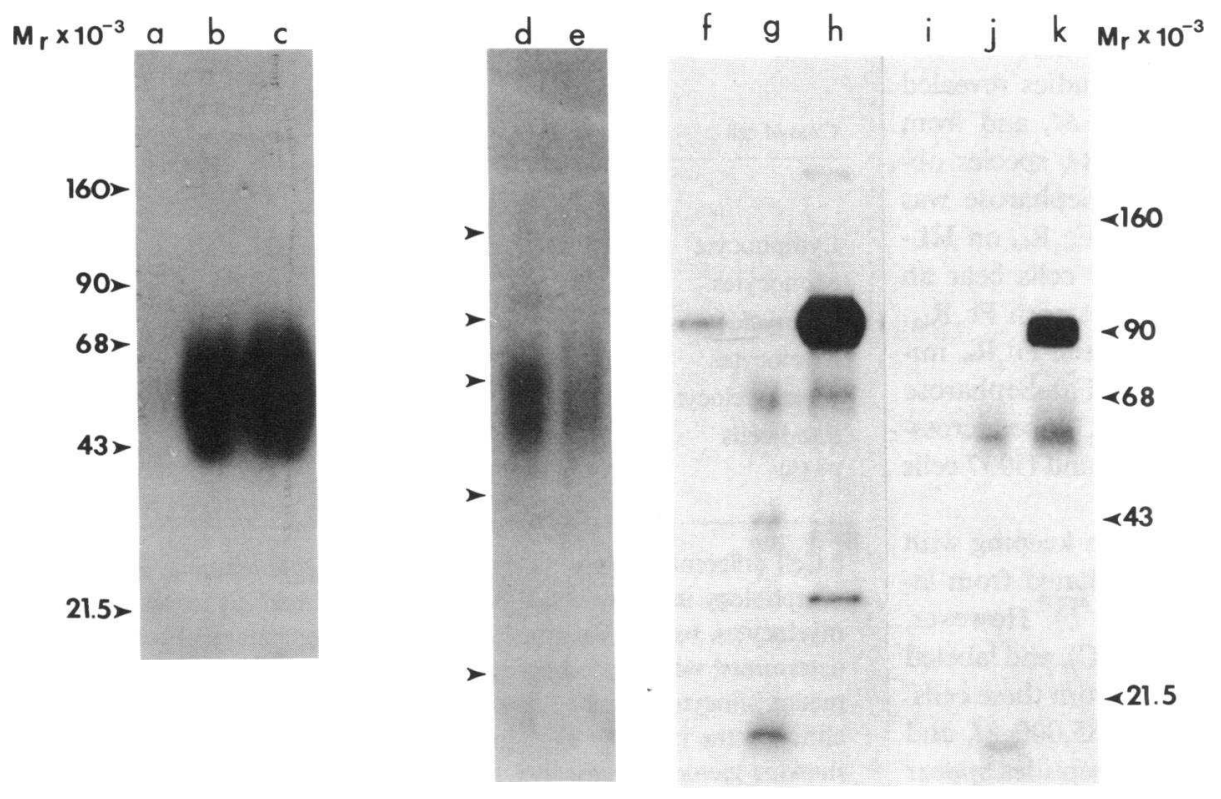

Figure 3. Polyacrylamide gel electrophoresis of iodinated proteins isolated from peripheral blood PMN, HL-60 cells, HL-60 cells treated with DMSO, and U937 cells. Lysates of PMN are in lanes $a-c$; lysates of HL-60 cells treated with DMSO are in lanes $d$ and $e$; lysates of HL-60 cells are in lanes $f-h$; and lysates of U937 cells are in lanes $i-$ $k$. Lanes $a, h$, and $k$ : lysates subjected to affinity chromatography on IgG1-Sepharose; lanes $b, d, g$, and $j$ : lysates immunoprecipitated with a rabbit anti- $-\mathrm{Fc}_{\gamma} \mathbf{R}_{\mathrm{lo}}$ serum adsorbed to $S$. aureus; lanes $c, e, f$, and $i$ : lysates immunoprecipitated with 3G8 FabSepharose. Molecular weight markers are: 160,000, Escherichia coli RNA polymerase alpha subunit; $90,000, E$. coli RNA polymerase beta subunit; 68,000 , BSA; 43,000 , ovalbumin; 21,500 , soybean trypsin inhibitor. 


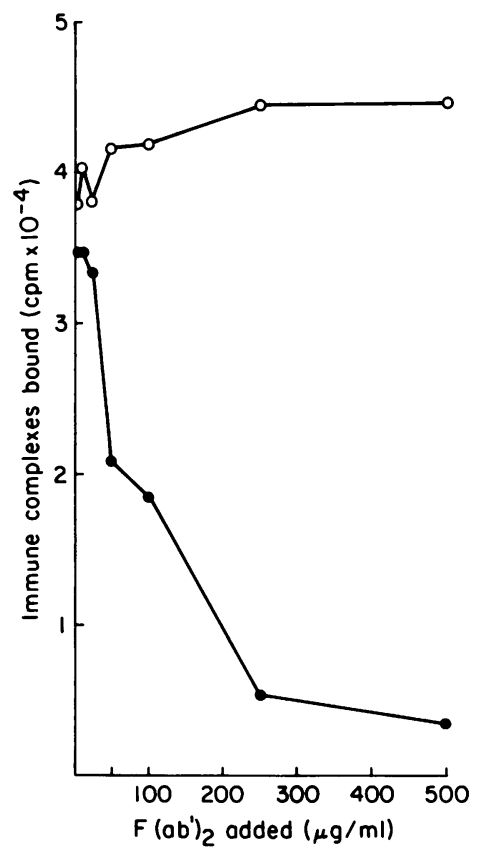

Figure 4. Inhibition of binding to neutrophils of soluble immune complexes by $\mathrm{F}\left(\mathrm{ab}^{\prime}\right)_{2}$ anti- $\mathrm{Fc}_{\gamma} \mathbf{R}_{\mathrm{lo}}$. Soluble immune complexes of rabbit anti-DNP IgG-DNP,BSA at a final concentration of $5 \mu \mathrm{g}$ $\mathrm{IgG} / \mathrm{ml}$ were added to neutrophils ( $\left.10^{6} / \mathrm{sample}\right)$ that had been preincubated for 1 $h$ with $F\left(a b^{\prime}\right)_{2}$ as noted. After $1 \mathrm{~h}$ of incubation the cells were washed by centrifugation. (0) control $\mathrm{F}\left(\mathrm{ab}^{\prime}\right)_{2} ;(\bullet)$ rabbit anti- $\left.\mathrm{Fc}_{\gamma} \mathbf{R}_{\mathrm{lo}} \mathrm{F}(\mathrm{ab})_{2}\right)_{2}$. All incubations were carried out at $4^{\circ} \mathrm{C}$.

immunofluorescence data (Figs. 1 and 2), 3G8 failed to precipitate 50,000 - to $74,000-M_{\mathrm{r}}$ proteins from untreated HL-60 or U937 cells (Fig. 3, lanes $f$ and $i$ ).

Affinity chromatography of NP-40 lysates from HL-60 or U937 cells on IgG1-Sepharose revealed polypeptides migrating from 62,000 to $68,000 M_{\mathrm{r}}$ and from 48,000 to $63,000 M_{\mathrm{r}}$, respectively, and a peptide centered at $90,000 M_{\mathrm{r}}$ (Fig. 3, lanes $h$ and $k$ ). No labeled protein was isolated from PMN lysates in parallel experiments (Fig. 3, lane $a$ ). We carried out immunoprecipitation studies on HL-60 and U937 cell lysates using the rabbit anti- $-\mathrm{c}_{\gamma} \mathrm{R}_{\mathrm{lo}}$ serum to determine if the serum crossreacted with the $\mathrm{Fc}_{\gamma} \mathbf{R}_{\mathrm{hi}}$ on these cells. These studies revealed broad bands migrating from 64,000 to $71,000 M_{\mathrm{r}}$ and from 48,000 to $55,000 M_{\mathrm{r}}$, respectively; the $90,000-M_{\mathrm{r}}$ species observed after affinity chromatography on IgG1-Sepharose was absent (Fig. 3, lanes $g$ and $j$ ). Since there is no $\mathrm{Fc}_{\gamma} \mathrm{R}_{\mathrm{lo}}$ on HL60 or U937 cells, these data suggest that these cells bear an $F c_{\gamma} R$ that shares some but not all antigenic sites with $F c_{\gamma} R_{l o}$ The similarity on SDS-polyacrylamide gels between $F_{\gamma} R_{l o}$ immunoprecipitated from neutrophils with 3 G8 Fab-Sepharose and the polypeptide isolated using rabbit anti-Fc $\mathbf{c}_{\gamma} \mathbf{R}_{\mathrm{lo}}$ sera crossreacting with determinants on uninduced HL-60 and U937 cells is noteworthy.

Uninduced HL-60 cells bear no CR3, and in keeping with this observation, no protein was immunoprecipitated from labeled HL-60 cells using OKM10 (Fig. 5, lane $b$ ). However, DMSO-induced HL-60 cells express CR3 (Fig. $2 C$ ), and labeled polypeptides were readily immunoprecipitated from these cells. Two peptides were observed, an $\alpha$-peptide of $185,000 M_{\mathrm{r}}$ and a $\beta$-peptide of $105,000 M_{\mathrm{r}}$ (Fig. 5, lane $c$ ). These peptides appear identical to CR3 of human macrophages. IB4 recognizes a family of proteins, of which CR3 is a member. Uninduced HL-60 cells express only one member of that family, a species with an $\alpha$ chain of $190,000 M_{\mathrm{r}}$ and a $\beta$-chain of 105,000 $M_{\mathrm{r}}$ (Fig. 5, lane $e)$. This species, therefore, is probably LFA-1. In contrast, induced HL-60 cells express three members of the family recognized by IB4. IB4 precipitates the $190,000 M_{\mathrm{r}} \alpha$-chain expressed in uninduced cells, the $185,000 M_{\mathrm{r}} \alpha$-chain of CR3, and a $153,000-M_{\mathrm{r}}$ chain, as well as the $105,000-M_{\mathrm{r}} \beta$-chain. These data suggest that the maturation of HL-60 cells is accompanied by the de novo expression of two members of the family recognized by IB4, CR3, and the uncharacterized species with a $153,000-M_{\mathrm{r}} \alpha$-chain.

\section{Discussion}

Our results demonstrate that $\mathrm{Fc}_{\gamma} \mathbf{R}_{\mathrm{lo}}$, recognized by monoclonal 3G8, appears late in myeloid development. Immunofluorescence studies of human leukemic bone marrow and peripheral blood leukocytes from patients with CML provide evidence that the antigen first appears at the metamyelocyte stage. These findings were extended by studies of the promyelocyte cell line HL-60, which does not bind 3G8 Fab. Induction of this cell line toward myeloid differentiation by DMSO or retinoic acid resulted in the expression of $\mathrm{Fc}_{\gamma} \mathrm{R}_{\mathrm{lo}}$ on a variable percentage of the population. Uninduced HL-60 cells express a high avidity Fc receptor for IgG1. Unfortunately, the IgG1 binding data we have amassed from control and DMSO-induced HL-60 cells are population averages, so we do not know whether the induced cells which

Table III. Expression of $F c_{\gamma} R_{l o}$ on Leukocytes from CML Patients

\begin{tabular}{|c|c|c|c|c|}
\hline \multirow[b]{2}{*}{ Class of cell } & \multicolumn{2}{|c|}{ Patient R.G. } & \multicolumn{2}{|c|}{ Patient S.H. } \\
\hline & $\begin{array}{l}\text { "Differential } \\
\text { counts }\end{array}$ & 3G8 positive & $\begin{array}{l}\text { Differential } \\
\text { counts }\end{array}$ & $3 \mathrm{G} 8$ positive \\
\hline & \% of total & \% of total & \% of total & \% of total \\
\hline Lymphocyte & 5 & & 32 & \\
\hline Monocytes & 2 & 0 & 2 & 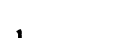 \\
\hline Promyelocytes & 18 & $\mathbf{U}$ & 19 & 1 \\
\hline Myelocytes & 4 & C & 38 & C \\
\hline Metamyelocytes & 19 & 16 & 4 & 7 \\
\hline Band cells & 17 & 12 & 2 & 2 \\
\hline PMN & 35 & 40 & 3 & 5 \\
\hline
\end{tabular}

* Cell differentials were determined by Diff-Quik staining. By nuclear morphology in fluorescence microscopy we could distinguish metamyelocytes, band cells, and PMN, and the percentage of cells thus determined was in good agreement with the Diff-Quik results. All the metamyelocytes, band cells, and PMN expressed $\mathrm{Fc}_{\gamma} \mathbf{R}_{\mathrm{lo}}$,

although the intensity of staining differed, with the more mature cells showing greater fluorescence intensity. 
Table IV. Expression of $F_{c_{\gamma}} R_{l o}$ on Leukocytes from Bone Marrow*

\begin{tabular}{|c|c|c|c|c|c|c|c|c|}
\hline Class of cell $\neq$ & AML & APL\$ & APLS & AMoL§ & AMoL & ALL§ & ALL§ & Mean values \\
\hline & & & & & & & & $\%$ \\
\hline Nonsegmented nucleus & 0 & 0 & 0 & 0 & 0 & 0 & 0 & 0 \\
\hline Metamyelocyte & 5.4 & 8.6 & 7.2 & 4.7 & 4.8 & 4.3 & 3.7 & 5.5 \\
\hline Band cell & 10.8 & 6.6 & 6.6 & 11.1 & 6.8 & 1.4 & 6.0 & 7.0 \\
\hline Polymorphonuclear & 48.5 & 53.0 & 45.2 & 26.9 & 44.9 & 17.9 & 24.6 & 37.3 \\
\hline
\end{tabular}

* Data are expressed as percent positive cells staining with 3G8 Fab. $¥$ Nuclear morphology was determined by immunofluorescence as described. § During remission.

express $\mathrm{Fc}_{\boldsymbol{\gamma}} \mathbf{R}_{\mathrm{lo}}$ also bind IgG1 with high avidity. However, since it is clear that myeloid cells before the metamyelocyte stage express Fc receptors $(14,33-35)$ but do not bind 3G8 IgG or $\mathrm{Fab}$, and mature neutrophils lack the high avidity $\mathrm{Fc}_{\gamma} \mathrm{R}_{\mathrm{hi}}$, there must be loss of $\mathrm{Fc}_{\gamma} \mathrm{R}_{\mathrm{hi}}$ during maturation. Whether this occurs by shedding from the plasma membrane, turnover and lack of replacement, or represents active loss of receptor due to degradation remains to be determined.

We have also used the inducible HL-60 cell line to order the sequence of appearance of new antigenic determinants. The expression of $\mathrm{Fc}_{\boldsymbol{\gamma}} \mathbf{R}_{\mathrm{lo}}$, as we have discussed, is a relatively late differentiation antigen. CR3, as measured by binding of OKM10, appears at an earlier stage of development (36), since after induction with DMSO $>99 \%$ of HL-60 cells are OKM 10 positive as compared with $24.3 \%$ that express $\mathrm{Fc}_{\gamma} \mathrm{R}_{\mathrm{lo}}$.

We have also studied the induction of Fc receptors on the U937 line following lymphokine treatment and on HL-60 cells

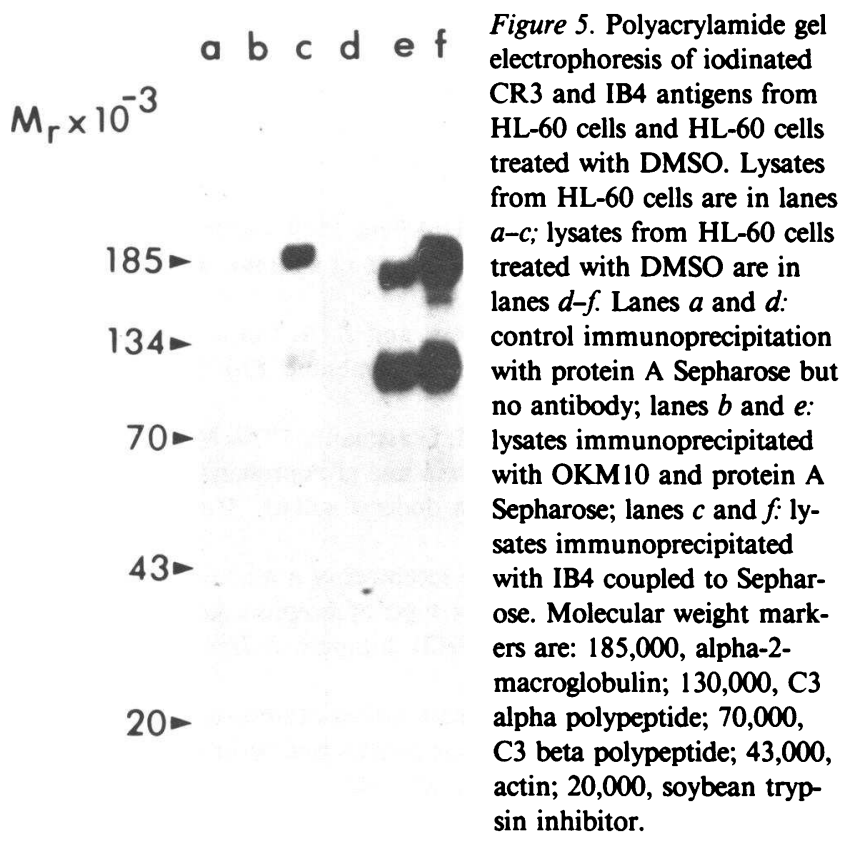

Figure 5. Polyacrylamide gel electrophoresis of iodinated 60 and IB4 antigens from HL-60 cells and HL-60 cells ed with DMSO. Lysates HL-60 cells se but recipitated actin; 20,000 , soybean trypsin inhibitor. following incubation with PMA. PMA treatment of HL-60 results in a threefold increase in IgG1 binding but no induction of $\mathrm{Fc}_{\gamma} R_{\mathrm{lo}}$. Guyre et al. (12) reported that the IgGl binding capacity of U937 cells was stimulated six- to eightfold by mixed leukocyte culture supernatants and by cloned gamma interferon (13). We demonstrate here that IgG1 binding by U937 is stimulated threefold by Con A supernatant, but find that there is no induction of $\mathrm{Fc}_{\gamma} \mathrm{R}_{\mathrm{lo}}$, demonstrating the independent regulation of the two Fc receptors. Similar independent regulation of mouse Fc receptors specific for IgG2b/IgG1 immune complexes and IgG2a has been reported (37-39).

There are several reports of purification of human Fc receptors in the general range of 40,000-70,000 $M_{\mathrm{r}}(40-42)$ by affinity chromatography on columns of immobilized IgG. We have explored the heterogeneity of human Fc receptors using affinity chromatography on IgG1-Sepharose, immunoprecipitation with monoclonal anti-Fc $\mathrm{F}_{\gamma} \mathrm{R}_{\mathrm{lo}}$ antibody $3 \mathrm{G} 8$, and immunoprecipitation with a rabbit serum elicited by $3 \mathrm{G} 8$-affinity purified $\mathrm{Fc}_{\gamma} \mathbf{R}_{\mathrm{lo}}$. As one might predict from the low avidity of the PMN Fc $\mathrm{C}_{\gamma} \mathrm{R}_{\mathrm{lo}}$ for $\operatorname{IgG} 1(2,3)$, we find nothing precipitated by affinity chromatography of PMN lysates on IgG1-Sepharose. However, from uninduced HL-60 and U937 cells, in agreement with others (40-42), we find a protein with broad electrophoretic mobility of $\sim 60,000 M_{\mathrm{r}}$, as well as a major peptide with a $M_{\mathrm{r}}$ of 90,000 . The rabbit anti-Fc ${ }_{\gamma} R_{\text {lo }}$ serum appears to cross-react with the $\mathrm{Fc}_{\gamma} \mathrm{R}_{\mathrm{hi}}$ on uninduced HL-60 and U937 cells since it immunoprecipitates the same diffuse protein of $\sim 60,000 M_{\mathrm{r}}$ observed following affinity chromatography on IgG1-Sepharose. The $90,000 M_{\mathrm{r}}$ peptide observed following affinity chromatography on IgG1-Sepharose is not immunoprecipitated by the rabbit anti-Fc ${ }_{\gamma} R_{1 o}$ serum. The identity of this protein is unclear. These results demonstrate the independence of $F c_{\gamma} R_{b o}$ and $F c_{\gamma} R_{h i}$ but also underscore the probability that these are closely related proteins, which could have been inferred previously only by the striking similarity of the isolated proteins upon polyacrylamide gel electrophoresis.

\section{Acknowledgments}

We thank Dr. Zanvil A. Cohn and Dr. Ellen Pure for their suggestions and careful reading of the manuscript, Dr. Gilla Kaplan and Judy Adams 
for photographic assistance, and Dr. T. Springer for sharing data prior to publication.

This work was supported by grants AI-14603 and CA-30198 from the U. S. Public Health Service.

\section{References}

1. Messner, R. P., and J. Jelinek. 1970. Receptors for human $\gamma \mathrm{G}$ globulin on human neutrophils. J. Clin. Invest. 49:2165-2171.

2. Kurlander, R. J., and J. Batker. 1982. The binding of human immunoglobulin G1 monomer and small cross-linked polymers of immunoglobulin G1 to human peripheral blood monocytes and polymorphonuclear leukocytes. J. Clin. Invest. 69:1-8.

3. Fleit, H. B., S. D. Wright, and J. C. Unkeless. 1982. Human neutrophil Fc receptor distribution and structure. Proc. Natl. Acad. Sci. USA. 79:3275-3279.

4. Perussia, B., O. Acuto, C. Terhorst, J. Faust, R. Lazarus, V. Fanning, and G. Trinchieri. 1983. Human natural killer cells analyzed by B73.1, a monoclonal antibody blocking Fc receptor functions. II. Studies of B73.1 antibody-antigen interaction on the lymphocyte membrane. J. Immunol. 130:2142-2148.

5. Wright, S. D., P. E. Rao, W. C. Van Voorhis, L. S. Craigmyle, K. Iida, M. A. Talle, E. F. Westberg, G. Goldstein, and S. C. Silverstein. 1983. Identification of the C3bi receptor of human monocytes and macrophages with monoclonal antibodies. Proc. Natl. Acad. Sci. USA. 80:5699-5703.

6. Sanchez-Madrid, F., J. A. Nagy, E. Robbins, P. Simon, and T. A. Springer. A human leukocyte differentiation antigen family with distinct $\alpha$-subunits and a common $\beta$-subunit: the lymphocyte functionassociated antigen (LFA-1), the C3bi complement receptor (OKM1/ Mac-1), and the p150,95 molecule. J. Exp. Med. 158:1785-1803.

7. Collins, S. J., F. W. Ruscetti, R. E. Gallagher, and R. C. Gallo. 1978. Terminal differentiation of human promyelocytic leukemia cells induced by dimethyl sulfoxide and other polar compounds. Proc. Natl. Acad. Sci. USA. 75:2458-2462.

8. Breitman, T. R., S. E. Selonick, and S. J. Collins. 1980. Induction of differentiation of the human promyelocytic leukemia cell line (HL60) by retinoic acid. Proc. Natl. Acad. Sci. USA. 77:2936-2940.

9. Honma, Y., K. Takenaga, T. Kasukabe, and M. Hozumi. 1980. Induction of differentiation of cultured human promyelocytic leukemia cell by retinoids. Biochem. Biophys. Res. Commun. 95:507-512.

10. Rovera, G., D. Santoli, and C. Damsky. 1979. Human promyelocytic leukemia cells in culture differentiate into macrophage-like cells when treated with a phorbol diester. Proc. Natl. Acad. Sci. USA. 76:2779-2783.

11. Koren, H. S., S. J. Anderson, and J. W. Larrick. 1979. In vitro activation of a human macrophage-like cell line. Nature (Lond.). 279:328331.

12. Guyre, P. M., G. R. Crabtree, J. E. Bodwell, and A. Munck. 1981. MLC-conditioned media stimulate an increase in Fc receptors on human macrophages. J. Immunol. 126:666-668.

13. Guyre, P. M., P. M. Morganelli, and R. Miller. 1983. Recombinant immune interferon increases IgG Fc receptors on cultured mononuclear phagocytes. J. Clin. Invest. 72:393-397.

14. Barrett, S. G., K. S. Hansen, and D. F. Bainton. 1981. Differentiation of cell surface receptors on normal human bone marrow myeloid precursors. Br. J. Haematol. 48:491-500.
15. Rabellino, E. M., G. D. Ross, H. T. K. Trang, N. Williams, and D. Metcalf. 1978. Membrane receptors of mouse leukocytes. II. Sequential expression of membrane receptors and phagocytic capacity during leukocyte differentiation. J. Exp. Med. 147:434-445.

16. Henson, P. M. 1969. The adherence of leukocytes and platelets induced by fixed IgG antibody or complement. Immunology. 16:107121.

17. Messner, R. P., and J. Jelinek. 1970. Receptors for human gamma globulin on human neutrophils. J. Clin. Invest. 49:2165-2171.

18. Böyum, A. 1968. Isolation of mononuclear cells and granulocytes from human blood. Isolation of mononuclear cells by centrifugation and sedimentation at 1 g. Scand. J. Clin. Lab. Invest. 21 (Suppl. 97):7789.

19. Horwitz, M. A., and S. C. Silverstein. 1981. Activated human monocytes inhibit the intracellular multiplication of Legionnaire's disease bacteria. J. Exp. Med. 154:1618-1635.

20. Berman, J. W., and R. S. Basch. 1980. Amplification of the biotin-avidin immunofluorescence technique. J. Immunol. Methods. 36:335-338.

21. Johnson, G. D., and G. M. de C. Nogueira Araujo. 1981. A simple method of reducing the fading of immunofluorescence during microscopy. J. Immunol. Methods. 43:349-350.

22. Porter, R. R. 1959. The hydrolysis of rabbit gamma globulin and antibodies with crystalline papain. Biochem. J. 73:119-126.

23. Fraker, P. J., and J. C. Speck. 1978. Protein and cell membrane iodinations with a sparingly soluble chloramide $1,3,4,6$-tetrachloro- $3 \alpha, 6 \alpha$ diphenylglycouril. Biochem. Biophys. Res. Commun. 80:849-857.

24. Unkeless, J. C., and G. A. Healey. 1983. Quantitation of proteins and internal antigen pools by a monoclonal sandwich radioimmune assay. J. Immunol. Methods. 56:1-11.

25. Fleit, H. B., and J. C. Unkeless. 1982. Purification of the human neutrophil Fc receptor by monoclonal antibody affinity chromatography. J. Cell Biol. 95 (2, Pt. 2):443a. (Abstr.)

26. Goudie, R. B., C. H. W. Horne, and P. C. Wilkinson. 1966. A simple method for producing antibody specific to a single selected diffusible antigen. Lancet. II:1224-1226.

27. Johansson, M. E., G. Wadell, P. A. Jacobsson, and L. Svensson. 1979. Preparation of specific antisera against adenoviruses by affinity bead immunization (ABI). J. Immunol. Methods. 26:141-149.

28. Hubbard, A. L., and Z. A. Cohn. 1975. Externally disposed plasma membrane proteins. I. Enzymatic iodination of mouse $\mathrm{L}$ cells. J. Cell Biol. 64:438-460.

29. Mellman, I. S., and J. C. Unkeless. 1980. Purification of a functional mouse Fc receptor through the use of a monoclonal antibody. $J$. Exp. Med. 152:1048-1069.

30. Kaplan, G., J. C. Unkeless, and Z. A. Cohn. 1979. Insertion and turnover of macrophage plasma membrane. Proc. Natl. Acad. Sci. USA. 76:3824-3828.

31. Neville, D. M., Jr., and H. Glassmann. 1974. Molecular weight determination of membrane protein and glycoprotein subunits by discontinuous gel electrophoresis in dodecyl sulfate. Methods Enzymol. 32:92-102.

32. Crabtree, G. R. 1980. Fc receptors of a human promyelocytic leukemia cell line: evidence for two types of receptors defined by binding of the staphylococcal protein A-IgGl complex. J. Immunol. 125:448453.

33. Scott, C. S. 1979. Maturation-linked expression of the Fc (IgG) receptor on developing human bone marrow and peripheral blood granulocytes. Clin. Exp. Immunol. 38:300-305. 
34. Burns, G. F., and J. C. Cawley. 1979. Membrane receptors of human leukaemic myeloid cells: sequential expression of the Fc receptor. Br. J. Haematol. 42:499-505.

35. Herborn, H. A., H. Valdimarsson, and S. M. Wickramasinghe. 1979. Development of human granulocyte and monocyte $\mathrm{Fc}$ receptors. Scand. J. Haematol. 22:364-368.

36. Talle, M. A., P. E. Rao, E. Westberg, N. Allegar, M. Makowski, R. S. Mittler, and G. Goldstein. 1983. Patterns of antigenic expression on human monocytes as defined by monoclonal antibodies. Cell. Immunol. 78:83-99.

37. Hamburg, S. I., H. B. Fleit, J. C. Unkeless, and M. Rabinovitch. 1980. Mononuclear phagocytes: Responders to and producers of interferon. Ann. NY Acad. Sci. 350:72-99.

38. Yoshie, O., I. S. Mellman, R. J. Broeze, M. Garcia-Blanco, and P. Lengyel. 1982. Interferon action: effects of mouse alpha and beta interferons on rosette formation, phagocytosis, and surface-antigen expression of cells of the macrophage-type line RAW 309.Cr1. Cell. Immunol. 73:128-140.

39. Ezekowitz, R. A. B., M. Bampton, and S. Gordon. 1983. Macrophage activation enhances expression of Fc receptors for IgG2a. $J$. Exp. Med. 157:807-812.

40. Kulczycki, A., Jr., L. Solanki, and L. Cohen. 1981. Isolation and partial characterization and $\mathrm{Fc}$ gamma-binding proteins of human leukocytes. J. Clin. Invest. 68:1558-1565.

41. Anderson, C. L. 1982. Isolation of the receptor for IgG from a human monocyte cell line (U937) and from peripheral blood monocytes. J. Exp. Med. 156:1794-1805.

42. Cohen, L., S. Shannan, and A. Kulczycki, Jr. 1983. Human monocytes, B lymphocytes, and non-B lymphocytes each have structurally unique Fc receptors. J. Immunol. 131:378-383. 